\title{
When the Law Distinguishes Between the Enterprise and the Corporation: The Case of the New French Law on Corporate Purpose
}

\author{
Blanche Segrestin $^{1}\left(\mathbb{0} \cdot\right.$ Armand Hatchuel $^{1} \cdot$ Kevin Levillain $^{1}$
}

Received: 16 June 2019 / Accepted: 13 January 2020 / Published online: 30 January 2020

(c) The Author(s) 2020

\begin{abstract}
A recent French reform has revised the legal definition of the corporation. In essence, the law stipulates that the corporation must be run with due regard to the social and environmental impacts of its activity. It also introduces the notion of raison d'être and affords the possibility for any corporation to assign social or environmental purposes to itself, defined in its bylaws. This reform is similar to recent reforms in the UK and the US, but is based on an original and distinctive theoretical argument. The aim of our article is to analyze the fundamental tenets of this reform and their implications for the theory of the corporation. It shows that the new law is based on a new positive definition of the enterprise as not only an economic organization or a productive entity, but more fundamentally a space for innovative collective action. We argue that this view of the enterprise challenges our conceptualization of the corporation in two important ways. First, it shows that the traditional theories overlook the activities of the enterprise and their related impacts, and that the corporation is not necessarily the appropriate legal vehicle for the innovative enterprise. Second, it suggests that the stipulation of the enterprise's purpose or raison d'être in the corporate by-laws can provide new promising legal foundations for corporate responsibility.
\end{abstract}

Keywords Corporate law $\cdot$ Corporate responsibility $\cdot$ Purpose-driven corporation

In May 2019, the French parliament passed a new law revising the definition of a corporation, especially the treatment of corporate purpose. This law introduces three elements: (i) an obligation to consider the social and environmental implications of the business activity; (ii) an option for any company to define its raison d'être; and (iii) a new type of corporate form, the 'société à mission,' for companies that adopt social or environmental goals by writing them into the company's by-laws and by setting up an ad hoc committee to monitor them.

Blanche Segrestin

blanche.segrestin@mines-paristech.fr

Armand Hatchuel

armand.hatchuel@mines-paristech.fr

Kevin Levillain

kevin.levillain@mines-paristech.fr

1 Mines ParisTech, PSL Research University, Centre de Gestion Scientifique (CGS), i3 UMR CNRS, 60 boulevard Saint Michel, 75006 Paris, France
This reform is a part of an international movement that started a few years ago, in particular with the introduction of new corporate forms, such as Benefit Corporations (BCs), which have now been written into the laws of 33 American states (André 2012; Hiller 2013; Hemphill and Cullari 2014). These new corporate forms were created in the US "to enhance CSR by providing legal protections to managements that want both to maximize shareholder income and to pursue a social or environmental agenda" (André 2012, p. 133). In France, the reform also aims to increase corporate social responsibility (CSR) and to restore trust in corporations, but the justification differs. Unlike the American case, in France a director does not have a specific fiduciary duty that would prevent him or her from prioritizing social and environmental goals over shareholders' interests. The introduction of the société à mission is motivated by another and original argument, as the Minister of Economy and Finance, Le Maire, stated during the parliamentary debates. $\mathrm{He}$ argued that the Napoleonic Code is "absolutely inadequate in so far it considers [the enterprise] from the angle of the corporation only (...). Renaming things and doing so 
truthfully is extremely important." [Bulletin Officiel: 9637, our translation].

This reform has come at a time when scholars are increasingly questioning the merits and legitimacy of the corporation (Clarke et al. 2019). While corporations indisputably create value for their various stakeholders, their interests are not necessarily correlated with the collective interest (Margolis and Walsh 2003; Scherer and Palazzo 2007; Lazonick 2014). As they have become global and extraordinarily powerful organizations, it has also become clear that they can threaten social equilibria as well as life itself on our planet (Metcalf and Benn 2012). Therefore, scholars are increasingly calling into question corporate governance and the legal features of the corporation, such as limited liability (Ireland 2010; Mayer 2013; Ciepley 2018). In this context, the French corporate law reform may be meaningful for the debate on the corporation and the legal conditions of corporate responsibility. The aim of the article is therefore to answer the following questions. First, why is it that distinguishing the enterprise from the corporation is so important and what are the fundamental tenets underpinning the amendment of the articles defining the corporation in the Civil Code, which had remained practically unchanged since 1804 ? Second, what are the theoretical implications of these arguments and to what extent do they challenge or enrich our views of the corporation?

We were able to collect extensive data relating to the period that saw the genesis of Articles 169 and 176 of the PACTE Law (Plan d'Action pour la Croissance et la Transformation des Entreprises [Action Plan for the Growth and Transformation of Business Enterprises], (2008-2018 period), as we were participating in a research program on the forms, foundations and possible reforms of French corporate governance. ${ }^{1}$ However, to characterize the theoretical background and implications of the reform, this article focuses specifically on the Notat-Senard Report. This report was commissioned in January 2018 by the French government from Notat and Senard, ${ }^{2}$ who were asked to look for ways to reconcile the interests of corporations and the collective interest. While various institutional reports have been produced over the past years on the topic of reforming corporate purpose, the Notat-Senard Report directly inspired

\footnotetext{
${ }^{1}$ Research Program at the Collège des Bernardins (2009-2018), led by Favereau (Roger 2012; Favereau and Roger 2015; Segrestin and Vernac 2018).

2 Nicole Notat is the former director of the CFDT (one of the leading labor unions) and the founder of the first extra-financial rating agency in France (Vigéo Eiris). Jean-Dominique Senard is currently the president of Renault but at the time was the CEO of Michelin. While it draws on several institutional reports, as well as almost 200 hearings, the Notat-Senard Report builds upon academic research to suggest a new theoretical view of the enterprise.
}

the final text of the law and was the main reference both in the parliamentary debates and in the press. It offered a detailed analysis of the issues, with sound arguments and evidence, and played a decisive role by synthesizing previous research and directly informing the government's draft bill. The report consists of 122 pages, with numerous historical and academic references. Its authors heard the testimony of more than 200 people within the span of a few weeks, most of whom were from the corporate world. ${ }^{3}$ Our analysis will therefore focus primarily on this report, its assessment of the current situation and contemporary challenges, and the justifications for the recommendations that it makes.

We show that the Notat-Senard Report proposes a change in corporate law based on a new positive view of the enterprise: It argues that the enterprise emerged very late, compared to the corporation, and as a distinctive economic organization. While the corporation - as a legal form - was already liberalized and widely used by merchants and producers to share profits and losses in the mid-nineteenth century, the modern enterprise emerged only at the very end of the nineteenth century, spawned by the upsurge of scientific and technological research and development in industry. This singular organization was not only productive and commercial but also creative: its purpose was not only to produce existing goods, but also to develop new goods and services, and therefore also to create new technologies, and new competencies, jobs and methods.

This view of the enterprise as a locus for collective creation challenges our conceptualization of the corporation in two important ways.

First, it shows that the corporation is not necessarily the appropriate legal vehicle for the enterprise. While the term 'corporation' is often used interchangeably with the term 'enterprise,' the literature has clearly distinguished the two words: the enterprise as the 'organized economic activity' on the one hand, and the corporation as a legal instrument or legal personhood on the other (Robé 2011; Deakin 2017). By doing so, the literature approaches the enterprise by default as just a reference to define the corporation. The NotatSenard Report shows that this approach to the enterprise by default is misleading because it overlooks why the enterprise has emerged only recently as a very distinctive form of economic organization. As the process of collective creation can directly impact our lifestyles and transform our societies, one has to take into account a contingency parameter which is the nature of the business and its purpose. Up until now, the theories of the corporation have disregarded the nature of the activities undertaken by the enterprise, as well as their ultimate purpose. We argue that it is necessary to reappraise

\footnotetext{
${ }^{3}$ Specifically, 57 people from the public sphere, 121 from the corporate sphere (including the non-profit sector) and 34 from academia.
} 
our distinction between the enterprise and the corporation, and to recognize that while the corporation was conceived as the legal vehicle for productive activity, it may not be the appropriate tool for the enterprise of collective creation.

Second, this new positive view also proposes that corporate responsibility cannot be considered independently of the activities undertaken and their objectives, and thus it entails new governance mechanisms. From this point of view, the French reform of corporate law adds to the growing body of research that is critically examining the legitimacy of the corporate form and exploring alternative forms. The French reform proposes that stipulating a raison d'être and the related social and environmental objectives in the by-laws of the corporation is a way to give a legal existence to the enterprise per se into corporate law. Therefore, enterprises are invited to clearly set out their intended contribution to society and the environment, and to proactively engage their responsibility for the futures they aim at producing. The reform thus invites us to consider the responsibility of the enterprise for the future it creates, and opens new avenues for scholars to think about the legal foundations of corporate responsibility.

The article is organized as follows. First, after some clarifications of the terminology used in relation to the enterprise and the corporation, we briefly review the different conceptualizations of the corporation and the various contemporary debates about how to increase CSR and to reconcile the corporate interest with the public interest. We show how these debates have led to different legal movements, including the movement of purpose-with-profits corporations in the US. In the second section, we present the French reform, first positioning it in the historical context and then comparing it with similar legal movements in the UK and the US. In the third section, our analysis of the Notat-Senard Report shows that while the French reform includes some of the features of these movements, it builds upon an original view of the enterprise. ${ }^{4}$ In the fourth section, we discuss the implications of this view, both on the theoretical distinction between the enterprise and the corporation, and on the ways to improve corporate responsibility in the twenty-first century.

\section{The View of the Corporation on Trial}

The corporation is often considered as "the primary instrument for wealth generation in contemporary economies," and its evolving role in society has called for multiple

\footnotetext{
${ }^{4}$ It is worth emphasizing that our aim is not to study the social movement dynamics (Djelic 2013) that resulted in the new law. Thus, it is not our intention to analyze the political scene or processes whereby different groups lobbied or influenced the reform.
}

interpretations (Clarke et al. 2019). In this section, we present the main theories of the corporation and the related debates in the literature before providing an overview of the reforms initiated or undertaken to make the corporation more sustainable and responsible.

\section{Enterprise vs Corporation}

To review the theories of the corporation, we first need to clarify the distinction between the words enterprise and corporation. While in French the words entreprise and société are clearly distinct, in the English-speaking world the terms 'enterprise' and 'corporation,' or 'firm,' are often used synonymously. For instance, O'Kelley states that "in a typological sense, the modern corporation is an American business firm characterized by separation of ownership and control" (O'Kelley 2019).

But these terms need to be distinguished. Robé argues that:

They correspond, however, to totally different concepts: a corporation is a legal instrument, with a separate legal personality, which is used to legally structure the firm; a firm is an organized economic activity, corporations being used to legally structure most firms of some significance (Robé 2011, p. 3).

Similar to Robé, several authors distinguish between the enterprise as an economic and/or productive organization and its legal vehicle, namely, the corporation (Teubner 1988; Robé 1999, 2011). For example, Chandler (1977) spoke of a "modern business enterprise" and not a modern corporation, as did Berle and Means (1932). Deakin views the enterprise as "an organization engaged in the production of goods or services, to which end it combines physical, human and virtual assets" (Deakin 2012, p. 350), while he defines the corporation as "a legal mechanism, and the principal legalinstitutional device through which business firms operate in contemporary market economies" (Ibid., p. 351). ${ }^{5}$

In our case, this distinction is important to avoid any translation issue from French. We will therefore use the term 'enterprise' in the same way as the French termentreprise to refer to the business organization, regardless of its legal

\footnotetext{
5 Similarly, Rajan and Zingales define the enterprise as the "unit of economic organization" (Rajan and Zingales 2000, p. 24), in contrast with the corporation, which is concerned with "ownership of assets" (Ibid., p. 25).
} 
form. ${ }^{6}$ By contrast, the term 'corporation' refers to the legal vehicle of business organizations. $^{7}$

\section{An Overview of the Theories of the Corporation}

The corporation is thus primarily a legal device. In its modern legal form, it has three singular features. Marie-Laure Djelic summarizes these three features in the following way:

First, it is treated as a fictional individual. As a legal entity in its own right, the corporation exists, potentially, in perpetuity [...]. As a legal entity, the corporation is protected by strong asset partitioning and it benefits from complete entity shielding.[...] Second, ownership of the modern corporation means the holding of shares. In its modern form, corporate ownership tends to be dispersed and shares are easily transferable and marketable.[...] Third, modern corporate share ownership is associated with the principle of limited liability. (Djelic 2013, p. 596).

To explain these legal features and interpret the role of corporate law, different theories have been put forward.

\section{State/Private and Aggregate/Separate Entities: The Main Dimensions}

We can roughly differentiate the theories of the corporation along two main lines. First, the corporation is seen as either a special entity, distinct from its shareholders, or as an aggregation of its members. Second, the corporation is either created by the state or is the result of private initiative. The prevailing doctrine in the early nineteenth century clearly recognized the corporation as an entity in its own right ["its power to sue and amenity to suit and its durational existence defined without regard to the lives of its shareholders" (Millon 1990, p. 206)]. The corporation was also 'artificial,' that is, it was created only though a special chartering by the state (Roy 2019). The privileges of limited liability were

\footnotetext{
6 The 'firm' is a fourth term, which we equate to the enterprise. Deakin et al. (2017, p. 194), for instance, distinguish the firm from the corporation as follows: "We use the term 'firm' to apply to individuals or organizations with the legally recognized capacity to produce goods or services for sale. A corporation is a kind of firm; it has a structure as designated under corporate law. All corporations are firms, but not all firms are corporations" (Deakin et al. 2017).

7 To avoid translation issues, we will clarify our choice of terminology. In line with American usage, we use the word 'company' (société in French) to refer to both the partnership and the corporation. But most of the time, we use the term 'corporation' (société anonyme in French) in reference to the public stock corporation, with legal personhood and limited liability. Similarly, we differentiate between the 'purpose' an enterprise can follow (without stipulating it in its by-laws) and the 'corporate purpose' [objet social] as the formally stated purpose in the by-laws of the corporation.
}

conferred only for the purpose of general welfare. In this view, the state is the source of managerial power, and the principle of ultra vires indicated that "a corporation could not bind itself contractually concerning a matter that was beyond the objectives defined in its charters" (Millon 1990, p. 209). Thus, the shareholders, even unanimously, could not create power not conferred by the state.

In contrast with the idea of an artificial entity created by the state, the corporation was later conceptualized in the twentieth century as a 'natural' entity (created freely at the private initiative of shareholders). This legal 'contractualism' (Dine 2000) was made possible by the liberalization of limited liability, the generalization of the standard of incorporation for any lawful purpose in the late nineteenth century, and the disappearance of the ultra vires doctrine (Djelic 2013; Ireland 2010; Guinnane et al. 2007, 2017). In the early twentieth century, the corporation was thus seen as a natural entity, albeit still as a separate legal entity. The separate legal entity was put forward in the attempts to conceptualize corporate social responsibility; it allowed managers to act as trustees of the corporation (Dodd 1932). But gradually, the legal contractualism made way to a more economic contractualism in which the corporation is no longer a separate entity. Instead, it is an 'aggregation' of its shareholders, with no distinct personality (Millon 1990; Dine 2000). Accordingly, the corporation has no separate existence, and is reduced to a mere nexus of contracts, with the shareholders as the main principals (Bratton 1989). The source of managerial powers then comes from the shareholders themselves, "with directors enjoying only such responsibility as actually was delegated" (Millon 1990, p. 215). Corporate law would thus be less concerned by the regulation of the corporation's relationship with society than by the internal aspects of corporate governance.

As we know from the literature on corporate governance, this view was widespread in the twentieth century. However, the debate is ongoing. Scholars have shown that considering the corporation as a nexus of contracts or as a "legal fiction" (Jensen and Meckling 1976) poses various problems. From an institutional perspective, the corporation is created by a "constitutional contract" (Grandori 2010): this type of contract not only regulates what is done or exchanged, but also how to decide. As it defines only decision procedures and rights, it is seen as an effective mode of governing under increasing levels of uncertain (Grandori 2010, 2019). Emphasis is also placed on the fact that the corporation is not a pure economic and transactional organization (Deakin et al. 2017). For example, the importance of entity shielding has been demonstrated (Hansmann and Kraakman 2000), along with that of corollary risks to the corporate veil (Millon 2007). Ciepley notes that "Entity shielding simply cannot be secured through private contract. It requires the legal fiat of the state. And incorporation can be seen as a 
substantial privilege bestowed upon a group by the state" (Ciepley 2018). The artificial nature of the corporation is also evident by virtue of the fact that the corporate contract creates a "sempiternal legal person" (Stout 2019), i.e., a person that can in theory exist forever.

\section{The Quest for Corporate Social Responsibility}

The model of the corporation as a private and aggregate entity has been criticized, mainly with regard to social responsibility. Following the early analysis of Dodd (1932), scholars have more recently revived the theory of the separate legal entity, which considers that, despite being created by private initiative, the corporation is an entity distinct from its shareholders (Blair and Stout 1999; Biondi et al. 2007; Veldman 2018). Thus, the corporation is not only a contract between shareholders formed to maximize their joint interests. The creation of a legal entity allows the corporation, precisely, to be a vehicle for a broader collective effort, invested in by multiple stakeholders and oriented towards their joint welfare (Blair and Stout 1999; Lan and Heracleous 2010). It is not necessary to include the various stakeholders as co-contractors in the corporate contract. Instead, it must be acknowledged instead that the board is in charge both of mediation and of allocating rewards fairly.

This theory of the separate legal entity has been very influential in contesting the shareholder view of corporate governance. However, does corporate law, as it stands, provide the appropriate governance to ensure that corporations act responsibly? As it is ultimately the shareholders who control the board and the top management (Kaufman and Englander 2005; Smith and Rönnegard 2016), one can doubt that directors have sufficient leeway to consider the various stakeholders equally. Even if corporations are under no obligation to maximize shareholders' returns, shareholders can be in a position to demand a quick return on their investment and then withdraw, even to the detriment of long-term sustainability (Mac Cormac and Haney 2012). In a nutshell, companies can pursue social and environmental goals only when their shareholders consent to it (Kaufman and Englander 2005; Sandberg 2011; Yosifon 2014). Today, given the huge challenges presented by inequality and climate change, scholars have started to discuss possible reforms of corporate law. Researchers are not only investigating governance that promotes leadership responsibility and sustainable corporate behavior (Filatotchev and Nakajima 2014; Starbuck 2014; Scherer et al. 2013), but they are also considering a redesign of the corporate form to facilitate sustainability. The corporate form "is ailing social technology" (Metcalf and Benn 2012); it pursues private interests but presumably with no interest in humanity. The legal features of the corporate form, such as limited liability, allow for certain irresponsible conducts (Ireland 2010; Ciepley 2018; Mayer 2013). And this is all the more worrying given that the new technologies that are being developed by contemporary corporations, such as artificial intelligence, are creating an unpredictable future (Mulgan 2018). While it was originally designed to facilitate economic development, "the corporate form now threatens human survival" (Metcalf and Benn 2012, p. 195).

One of the many proposals designed to reduce corporate irresponsibility (e.g., changes in CEO compensation) is to allow a majority of the voting stock of a corporation to be held by a non-profit organization, or "industrial foundation" (Mayer 2013; Ciepley 2018). Such shareholder foundations "are normally chartered for combined business and charitable purposes" (Ciepley 2018, p.1015). Their main advantage would be to insulate the control of the corporation from the influence of short-term shareholders and allow for the needs of various stakeholders to be taken into consideration in the long run. This is, however, very demanding as it requires stocks to be voluntary transferred to non-profit foundations.

\section{International Legal Movements}

Two other streams have emerged in the US and the UK: one that extends the duties of directors with respect to various stakeholders, and one that creates new corporate forms with expanded corporate purposes.

\section{Expanding the Duties of Directors}

Both the US and the UK preceded France in terms of addressing the social and environmental duties of company directors. Specifically, the UK Company Act of 2006 stipulates in Section 172 that administrators must act for the success of the company and for the benefit of its members, and in so doing must consider the effects of their decisions on the interests of employees and other parties (Keay 2007). This provision followed a wave of constituency statutes in various American states that either allowed or required, depending on the case, company directors to take into consideration the interests of different stakeholders (Bainbridge 1992; Bisconti 2009; Orts 1992).

\section{New Corporate Forms with Expanded Purposes}

While an expansion of fiduciary duties concerns all companies, an alternative was to introduce new corporate forms as an option rather than an obligation (McMullen and Warnick 2016). Following the creation of Community Interest Companies in England in 2004, the first BCs were introduced in Maryland in the US in 2010. In 2012, California simultaneously introduced the $\mathrm{BC}$ and the Flexible Purpose Corporation [later relabelled the Social Purpose Corporation (SPC)]. Today, the BC has been adopted in 31 states in the US (Hiller 2013) and has spread beyond the US to Latin 
America and Europe (e.g., Società Benefit in Italy in 2014). While profit-with-purpose corporations take several different forms, depending on the state, with different missions and different evaluation or enforcement mechanisms, the general framework is relatively fixed (Clark and Babson 2012; Deskins 2012; Hemphill and Cullari 2014; Hiller 2013; Michelle 2017; Rawhouser et al. 2015) and can be summarized as follows: they adopt "(i) a corporate purpose to create a material positive impact on society and the environment; (ii) expanded fiduciary duties of the directors requiring the consideration of non-financial interests; and (iii) an obligation for the corporation to report on its overall social and environmental performance" (Hemphill and Cullari 2014, p. 520). The French reform, as we will see in the next section, introduces the same framework in corporate law, but with additional features and distinctive justifications.

\section{The Context of the French Reform}

\section{The French Reform from a Historical Perspective}

While the historical background may be quite similar in other countries (Djelic 2013; Ireland 2010; Guinnane et al. 2007, 2017; Ciepley 2018), it is important to contextualize the present reform in the history of French corporate law, in particular regarding the role played by the corporate purpose.

In France, following the abolition of guilds and their equivalents during the French Revolution, the Civil Code under Napoleon formally recognized the possibility of incorporation with limited liability, but defined it cautiously. The corporation was introduced into commercial law in 1807. At the time, the corporate purpose played an essential role, revealing a conceptualization of the corporation as both a separate legal entity and a state creation:

- First, corporations could no longer be known by the names of their owners: "A corporation [société anonyme] is anonymous. It is only known by the description of its purpose" [the first draft of the code (year IX) in LefebvreTeillard (1985)].

- Second, given the risk of fraud and traps for investors, the creation of a corporation was subject to special authorization from the government. This authorization was granted following an in-depth examination of the corporate purpose to see whether the public call for investors was justified and whether the company had a chance of success.

- Finally, corporate purpose was also a way to define the latitude granted to the directors responsible for running the business, based on the doctrine of ultra vires
Examination and authorization procedures gradually came to be viewed as increasingly burdensome, but the experience helped to develop a series of rules relating to the incorporation of corporations. The law for instance gradually introduced the requirement of a minimum amount of capital, as well as a special auditor (commissaire aux comptes). Following numerous heated debates, government authorization was finally done away with in 1867 in the name of freedom of association. From then on, corporate purpose was no longer subject to the formal control of the state, and could be freely determined, as long as it was legal (Lefebvre-Teillard 1985).

This freedom has not been called into question since then. Several jurists have noted that corporate purpose was progressively likened to sectors of activity ["fields of possibilities" (Vernac 2015)] and was often worded very broadly (e.g., "for any lawful purpose") to preclude the risk of directors overstepping their authorization. To our knowledge, no proposals were made in the twentieth century in France to reform corporate purpose. It was only recently, in 2017, that the concept was taken up again in government reflection.

\section{The Rise of Corporate Purpose as a Policy Issue in 2017}

In October of that year, President Emmanuel Macron mentioned in a televised speech the need to "redefine the enterprise" and its purpose. At the time, the French Ministry of Economic Affairs and Finance had just launched a largescale consultation to prepare the PACTE law, the objective of which was to rebuild French citizens' 'trust' in business (cf. Club des Juristes 2018, p.15).

One of the components of this consultation was a commission that examined issues of value creation through governance, the involvement of employees in value creation (e.g., profit-sharing, employee shareholdings), and company stakeholders as contributors to sustainable value (Bercy 2017, p. 8). However, even before the report of this commission was published, the Ministry of Labour wished to strengthen this component and convened a government meeting on corporate purpose on 5 January 2018. In addition to Muriel Pénicaud, the Minister of Labour, the participants in this meeting were Nicole Belloubet, the Minister of Justice, Nicolas Hulot, the Minister for the Ecological and Solidary Transition, and Bruno Le Maire, the Minister of Economy and Finance. All the social partners (trade union leaders) were also invited (Barthet 2018). At this meeting, the ministers expressed their wish to prepare a more ambitious reform, and commissioned Nicole Notat and JeanDominique Senard to draw up a report on the relationship between corporations and the collective interest. Considering the growing societal expectations with respect to business enterprises, the ministers thought it was necessary to 
Table 1 The Key amendments of the Articles 169 and 176 [our translation]

Article 1833 of the Civil Code is completed as follows: "The company should be managed in its own self-interest, while considering the social and environmental impact of its operations"

Article 1835 is completed as follows: "By-laws can specify a raison d'être, consisting of the principles that the company adopts, with respect for these principles taking place through the company allocating resources to them as a part of its operations"

The Company Law [in the Code of Commerce] is modified. Extract:

"Art. L. 210-10.-A société à mission is a corporation that has a raison d'être in line with Article 1835 of the Civil Code, the by-laws of which:

"1. Define a mission of pursuing social and environmental goals in accordance with its raison d'être;

"2. Define the composition, operation, and means of a corporate body, separate from the bodies established by the present book, which must contain at least one employee, and which is exclusively responsible for successfully fulfilling the mission indicated in Item 1"

forge a new vision of the firm by examining its role, legal framework and mission.

The letter of intent, dated January 11, 2018, shows that the task entrusted to Notat and Senard was ambitious, and was aimed at reopening a discussion around corporate purpose:

Our idea is to open up the field of possibilities and consider all levers allowing any stakeholders that so desire to give an enterprise a wider corporate purpose [objet social]. In short, this means giving an enterprise a purpose that is not exclusively guided by short-term considerations, thus promoting a vision of capitalism that is more respectful of the general interest and that of future generations. [our translation]

The schedule was very tight, as the report had to be submitted by March 1, 2018. While various institutional reports had been produced over the years on reforming corporate purpose, the Notat-Senard Report provided a detailed analysis of the issues and a clear justification for its proposals. It played a decisive role by offering a synthesis of previous research, and directly informed the government's draft bill.

\section{The Core Elements of the Law}

The report was published in March and the resulting bill did the rounds in April. Chapter 3 of the bill concerned "fairer businesses," and the second section was titled "Rethinking the place of companies in society." This section incorporated Notat and Senard's main recommendations, albeit watered down. The suggestions of the Notat-Senard Report were raised in parliamentary debates, and after several consultations, the National Assembly validated the report's suggestions on October 5, 2018. They were partially vetoed by the Senate, but finally reintroduced by the National Assembly on March 16, 2019. The final version was approved by the Senate on April 9, 2019 and by the National Assembly on April 11, 2019.

Table 1 summarizes Articles 169 and 176 of the PACTE. It shows three key elements of the reform: (1) a "consideration clause," i.e., the obligation to consider the social and environmental implications of a corporation's activities, (2) the possibility for a corporation to define its raison d'être, and (3) a new status of société à mission.

\section{The French Reform in Comparison to the US and UK Movements}

The French reform must not be taken out of its international context. In this particular case, it clearly borrows from other legislative developments that preceded it, mainly in the US and the UK, but the French position differs from the other reforms in several ways. The differences can be characterized along three main dimensions (see Table 2):

- First, the French law combines two paths that could be seen as alternatives: a general obligation for companies to consider social and environmental issues, and an option for a company to make social and environmental commitments.

Table 2 The French reform in comparison to the US and UK reforms

\begin{tabular}{|c|c|c|c|c|c|c|}
\hline \multicolumn{3}{|c|}{ General path: expansion of fiduciary duties for company directors } & $\begin{array}{l}\text { France: Optional path } \\
\text { raison d'être }\end{array}$ & \multicolumn{3}{|c|}{ Optional path: creation of a company with an extended corporate purpose } \\
\hline $\begin{array}{l}\text { Authorization for com- } \\
\text { pany directors to take } \\
\text { multiple stakeholders } \\
\text { into account }\end{array}$ & $\begin{array}{l}\text { Requirement for directo } \\
\text { ers (or the legal entity) }\end{array}$ & $\begin{array}{l}\text { o take multiple stakehold- } \\
\text { to account }\end{array}$ & $\begin{array}{l}\text { Possibility for a com- } \\
\text { pany to formulate its } \\
\text { raison d'être }\end{array}$ & $\begin{array}{l}\text { Company commitment } \\
\text { based on standardized } \\
\text { criteria }\end{array}$ & Company commi & ed on a specific purpose \\
\hline e.g., Constituency statutes & e.g., UK Company Act & $\begin{array}{l}\text { France: Corporate interest } \\
\text { (interest of the legal } \\
\text { entity) while consider- } \\
\text { ing social and environ- } \\
\text { mental implications }\end{array}$ & & $\begin{array}{l}\text { Benefit corporations: } \\
\text { Evaluation standard } \\
\text { Third-party auditing }\end{array}$ & $\begin{array}{l}\text { SPC: } \\
\text { Purpose } \\
\text { Public reporting }\end{array}$ & $\begin{array}{l}\text { France: } \\
\text { Mission } \\
\text { With a distinct committee } \\
\text { representing multiple } \\
\text { stakeholders to evaluate } \\
\text { the respect of the purpose }\end{array}$ \\
\hline
\end{tabular}


- Second, concerning the general obligation, the French law, like the UK one, stipulates that companies must be managed in the corporate interest [intérêt social]. However, while the UK law defines the success of the company as the objective, and the means to ensure that the stakeholders' interests are taken into consideration, the French law stresses that the company's interests do not guarantee the consideration of social and environmental aspects. The idea is not only to manage a company in its own interests, but also expressly to consider the social and environmental impacts of its operations.

- Third, regarding the option to make social and environmental commitments, the French law, contrary to US BCs (but similar to SPCs), does not establish standardized assessment frameworks, leaving it up to the sociétés à mission to define both their mission and their evaluation methods. It does nonetheless require the creation of a special committee to monitor the execution of the mission and to report to the board, as opposed to SPCs, which leave it entirely up to the board of directors to evaluate the strategy with respect to the mission (in which case a decree must subsequently specify the publicity and reporting methods).

\section{Theoretical Background: A New Positive View of the Enterprise}

While they have many similarities, the starkest contrast between the French reform and those in other countries concerns their justification. The Notat-Senard Report follows the US movement's analysis of the limitations of corporate law in relation to corporate responsibility, but it differs in its 'positive' approach to the enterprise. Usually, as noted above, the enterprise is seen as the substratum of the corporation: the 'economic activities.' By 'positive approach' we mean, on the contrary, the elements that characterize the distinctive features of the enterprise. While business organizations or 'organized economic activities' have always existed, the enterprise has a recent history and a specific rationale. To justify its proposals, it builds upon academic research to advance a new view of the enterprise, with a purpose of collective creation.

Rather than considering enterprises as the root cause of our current sustainability challenges, the report suggests reversing the viewpoint, arguing that enterprises are "a part of the solution." Its recommendations are based on three original positions: (i) the 'enterprise' (entreprise) must be distinguished from its legal vehicle, which is the company (société); (ii) it is the collective capacity to create that distinguishes the enterprise and that contributes to the collective interest; and (iii) defining the raison d'être of the enterprise within the corporate contract protects the enterprise in this capacity, and therefore also protects the collective interest.

Let us consider these propositions in detail.

\section{Collective Creation as the Driver of the Modern Enterprise}

Based on past research (Robé 1999, 2011), the Notat-Senard Report starts by emphasizing the importance of distinguishing the enterprise [entreprise] from the corporation [société]. In terms of French law, the corporation is formed by shareowners who agree, by contract, to appropriate property for a common venture. But employees, for instance, are not part of this contract; they are only a third party. The enterprise, which is the term currently used to denote the organization invested primarily by employees and managers, is not defined in the law.

The Report adds a historical perspective, based on recent academic work (Segrestin and Hatchuel 2012; Favereau 2014; Favereau and Roger 2015), to distinguish between the corporation and the enterprise. While the corporation was liberalized in France in 1867 (and also around the midnineteenth century in England, Germany and the United States), the modern enterprise only emerged at the very end of the nineteenth century. It was not until the beginning of the twentieth century that the employment contract [contrat de travail] replaced the personal service contract [contrat de louage], which was classified in the 'law of things' and was highly contractual and commercial in nature, such as client - supplier contracts between the employee and the employer (Deakin 2009) (Notat-Senard Report, pp. 25 - 26). This was also the period during which professional management and the role of executives emerged as distinct functions, separate from those of directors. Why has the enterprise, with its complex contractual relationships, emerged?

The report suggests that the modern enterprise emerged during this period not only as a result of industrial development and the concentration of capital. The modern enterprise cannot be fully comprehended as an alternative model of production (Perrow 2002), nor as an integration of various functions designed to address the growing complexity of industrial activities (Chandler 1990). It can be understood only by considering the rise of a new regime of activity that emerged when technical inventions and technological progress were becoming collective and organized activities, and a new generation of engineers and researchers began to join companies. "They became aware that invention is an activity that can (and must) be both collective and governed" (Segrestin and Hatchuel 2012, p. 27, quoted on page 25 of the Notat-Senard Report). It is "collective creation, inventive activities, and the organization of innovation that constitute the core of the industrial enterprise, and that 
grant it its legitimacy" (p. 25, our translation). New types of organization emerged to organize and systematize innovation, and with them new industrial relationships arose. Professional management and business administration courses appeared. Supplier - purchaser-style contracts with workers were clearly no longer sufficient, for to develop electricity, automobiles, or synthetic fertilizers, it was necessary to develop new competencies and new methods. The employment contract, based on the principle of subordination, was seen as a way to train workers and to make them adopt new and changing collective methods.

This distinction between the enterprise and the corporation, and the conceptualization of the enterprise as a dynamic of collective creation are borrowed from academic research (Segrestin and Hatchuel 2012) and play a central role in the Notat-Senard Report, in which the term 'collective creation' appears nine times: the enterprise is "created only if it addresses a specific need, and remains only if it maintains a dynamic of invention, innovation, and collective creation" (p. 4, our translation).

\section{Collective Creation: Why the Enterprise Must be Protected}

From this point of view, Notat and Senard note a kind of historical mismatch between the law and the rise of the modern enterprise. During the twentieth century, different branches of the law had to deal with the enterprise, primarily labor law, but also areas such as competition law and tax law. However, corporate governance remained within the domain of corporate law, which hardly changed at all. Business officers have continued to be hired and mandated by shareholders in accordance with the rule of corporate law as if there had been no fundamental transformation of business organizations from classical companies to modern enterprises.

While the innovative aspect of the enterprise contributes to the general interest, the paradox pointed out by the NotatSenard Report is that governance practices tend to "empty the enterprise of its substance" (p. 19). For example, the short-termism of investors can limit R\&D efforts (Auvray et al. 2016). Therefore, the issue is, above all, not to relinquish profits, but to restore the role of the enterprise and its capacity to generate value beyond profits.

\section{Raison d'être as a Way to Protect the Enterprise}

From this distinction between the enterprise and the corporation, the Report concludes that the enterprise has until now been lacking a legal vehicle consistent with its creative nature. Because of its innovative nature, the enterprise can affect the society and the environment both negatively or positively. Thus, the following legal changes are suggested:
- On the negative impact of the enterprise, this led to the recommendation to amend the Civil Code by adding a 'consideration clause' to Article 1833: The enterprise cannot be run in the sole interests of the shareholders or in the interests of the private corporation. Corporate law should consider the activities and their social and environmental impacts. No enterprise should be managed without due regard to the impacts of the related activities.

- On the positive contribution of the enterprise, the report recommends two additional provisions: the board of any corporation can define the raison d'être [of its enterprise]; and if the shareholders so desire, the raison d'être can be translated into objectives written into the by-laws, thus making it a contractual commitment. Accordingly, the entreprise à mission status defines its purpose with specific social and environmental objectives in the by-laws. Here again, the report draws on academic research (Segrestin et al. 2015; Levillain 2017). The entreprise à mission makes CSR initiatives credible and avoids greenwashing as the objectives contractually bind the corporation. By specifying the mandate of directors, the contractual objectives also increase directors' leeway to refuse excessive demands for profits from shareholders. The entreprise à mission thus secures long-term collective efforts for desirable futures.

From our point of view, the combination of these three points (a consideration clause, defining a raison d'être, and entreprise à mission status) defines the Notat-Senard Report's scope and originality. All three elements have now been enshrined in the law.

\section{Discussion: Enriching our Theories of the Corporation}

The PACTE law has just passed in France and it is too early and out of the scope of our paper to analyze the practical consequences of the changes it introduced. Modifying the purpose of the corporation is obviously something that has raised questions, and several commentators have already expressed their concerns, which often overlap with debates in the UK and the US. For instance, will this change be a source of rapidly increasing litigation (Yosifon 2017)? Will entreprises à mission only concern a small number of companies? Will greenwashing actually be prevented (Rawhouser et al. 2015)? However, beyond these issues, the theoretical reach of the French law has frequently been pointed out. ${ }^{8} \mathrm{Next}$, we examine more closely some of the theoretical implications of this reform.

\footnotetext{
${ }^{8}$ Some commentators speak not only of a change in mindset "by taking the general interest on board in their concerns," but also of a "paradigm shift," a "renewal of liberalism," or even "a conceptual revolution"; the law is seen to create "a fundamental hole in the 'Friedmannian' conceptualization."
} 


\section{Is the Corporation the Appropriate Vehicle for the Enterprise? Towards an Enriched Theory of the Corporation}

The French law brings to light a parameter that was previously not visible in the approach to the corporation. As noted above, the theories of the corporation have fluctuated in two respects: the aggregate versus separate entity dimension, and the private/natural initiative versus state creation dimension. The Notat-Senard Report mentions these controversial issues. However, it suggests a need to change the focus: in both dimensions, the questions of what the activity of the enterprise will be, and what the enterprise will effectively do to society, play no role.

The distinction introduced earlier between the enterprise and the corporation is fully realized here. This absence of a reference to the activity of the enterprise has largely contributed to the unhinging of the corporate framework from contemporary business. Since the mid-nineteenth century, the corporation has been a legal tool concerned only with share capital: (i) some owners contribute to the share capital by investing their assets; (ii) the corporation is formed as a legal entity, which owns the share capital; and (iii) the constitutional contract defines the respective rights-including the control rights-and liabilities of the asset providers. Rajan and Zingales (2000) noted that in the nineteenth century, the ownership of capital ensured the ownership of the means of production and therefore value creation. However, is this approach still valid today? Rajan and Zingales consider that in modern economies, "since ownership is relatively unimportant, and human capital is not tied to inanimate assets, the legal definition of the firm, which centers around the ownership of the inanimate assets, is not very helpful" (Rajan and Zingales 2000). However, Rajan and Zingales continue to see the enterprise as the "unit of economic organization" (Ibid., p. 25), and do not make any proposal to change the law. By contrast, the French reform is based on the idea of a historical differentiation between classical capitalist organizations and modern ones, arguing that the creative nature of the modern enterprise calls for a change in the law. By virtue of its creative nature, modern enterprises can change the world, just as BASF in the early twentieth century with its synthetic fertilizers and as Monsanto more recently with its glyphosate, changed the world (positively or negatively). Corporate law allows them to do so, in the interests of the shareowners, or at best in the interests of the corporation itself. This can explain in part why the corporation has become an "ailing social technology" (Metcalf and Benn 2012).

The main theoretical implication, from our standpoint, derives from the new view of the enterprise. As noted above, the literature has already distinguished the enterprise, as an economic (productive) organization, from its legal vehicle, the corporation. But if we follow the French argument, the enterprise is not just an economic organization, nor is it just a productive organization; it is a creative organization. Therefore, we must recognize that although the corporation was conceived as the legal vehicle for productive commercial activity, it is not necessarily the appropriate legal vehicle for the creative enterprise (see Table 3).

Therefore, the question is, what is the appropriate legal vehicle for the enterprise? How should the law recognize the creative enterprise and hold it responsible?

\section{Purpose-Driven Corporations as the Legal Form for Responsible Enterprises?}

In this respect, it seems that the French reform does a good job of making visible the activities of the enterprise and their effects, as it mentions both the impact of those activities and their purpose in the law. Thus, it informs the growing body of research that explores the possible linkages between corporate law and corporate responsibility (Aguilera et al. 2015; Ciepley 2018, Filatotchev and Nakajima 2014; Grandori 2019; Mayer 2013; Scherer and Voegtlin 2017).

Table 3 The distinction between enterprise and corporation revisited

\begin{tabular}{|c|c|c|}
\hline & Economic activity & Legal vehicle \\
\hline Productive activity & $\begin{array}{l}\text { Organization engaged in productive activity } \\
\text { "Organized economic activity" (Robé } 2011, \text { p. } 3 \text { ) } \\
\text { "An organization engaged in the production of goods or ser- } \\
\text { vices, to which end it combines physical, human and virtual } \\
\text { assets" (Deakin } 2012, \text { p. } 350 \text { ) } \\
\text { "Unit of economic organization, which they call the } \\
\text { 'enterprise"'(Rajan and Zingales 2000, p. 24) }\end{array}$ & $\begin{array}{l}\text { Corporation } \\
\text { "A legal mechanism, and the principal legal-institutional } \\
\text { device through which business firms operate in contem- } \\
\text { porary market economies" (Deakin 2012, p. 351) } \\
\text { "Constitutional contract" (Grandori 2010) } \\
\text { "Separate legal entity" (Blair and Stout 1999) } \\
\text { "Ownership of assets" (Rajan and Zingales 2000, p. 25) }\end{array}$ \\
\hline Creative activity & $\begin{array}{l}\text { Entreprise } \\
\text { "Organization of collective creation processes" (Segrestin and } \\
\text { Hatchuel 2011) } \\
\text { "Organized collective creation" (Segrestin and Hatchuel 2012; } \\
\text { Notat and Senard 2018) }\end{array}$ & \\
\hline
\end{tabular}


In terms of social and environmental responsibilities, the French reform introduces a new proposal that revisits the classical debate on the nature of the corporation as either a private initiative or a state one. The specification of a raison d'être or mission means that the corporate purpose cannot be reduced to the interests of the shareowners, thereby clearly implying that the corporation is a separate legal entity. But it goes further than that: the private interest of the corporation cannot be the sole guide for business leaders. The corporation must avoid negative impacts and must integrate due regard to social and environmental impacts. It can also pursue positive impacts and integrate other parties' interests, and even the public interest. Interestingly, the new French law proposes a path that goes beyond the classical opposition between the corporation viewed as private or a state initiative. The purpose of the corporation is freely determined by private initiative but does not amount to a private interest.

Second, the French reform introduces a new conceptualization of the enterprise, one that is not limited to a for-profit organization. By referring to the activities of the enterprise beyond the constitution of joint stock for the corporation, it makes the enterprise exist legally. In this way, the French reform builds upon former cases. For instance, industrial foundations are already set up with a clear commitment to a purpose. However, most of the time, industrial foundations are seen as a way of combining the profit objective with a charitable one (Ciepley 2018). Fundamentally, they do not change the view that the enterprise is a for-profit 'economic organization,' devoted to maximizing profits. By contrast, the French law stipulates that the enterprise can be intrinsically constituted to pursue broader and more diverse aims. The purpose of the enterprise's activities needs to be specified because the entrepreneurial aim is not necessarily to maximize profits. In other words, the definition of the raison d'être in the law makes visible the enterprise as an entity distinct from the corporation, and allows entrepreneurial projects to pursue goals other than profit maximization.

Finally, we believe that the French reform has paved the way for a new approach to corporate responsibility. It is now acknowledged that responsible businesses must not only "avoid doing harm" but also aim to "do good" (Scherer and Voegtlin 2017). In this respect, the innovative capabilities of the enterprise raise concerns as well as expectations. Business enterprises can contribute to alleviating hunger or speeding up the transition to renewable energy sources. By defining their purpose, corporations can now make explicit how they see their responsibility, that is, the contribution they intend to make, and to which they are committed.

As Grinbaum and Groves (2013) noted, "we have to acknowledge that the responsibility associated with innovation necessarily is responsibility for the future it helps to create" (Grinbaum and Groves 2013). In this respect, purpose-driven corporations provide new and promising legal foundations for enhanced CSR.

\section{Conclusion}

In essence, the French reform changes the framework of business responsibility in two ways. First, it obliges corporations to run their business with due regard to the impacts of their activities. Second, it opens up the possibility of a company defining its raison d'être and becoming, on a voluntary basis, a société à mission. Thus, a company can adopt a purpose that does not renounce profit-making or shareowners' interests, but that expressly includes the pursuit of social and environmental goals.

In this study, we have shown that France's recent reform is part of an international movement, but is underpinned by novel theoretical arguments. The reform introduces a new conceptualization of the enterprise as an organization that has emerged with a creative purpose. We argue that this new conceptualization has important theoretical implications. First, it shows that the corporation is not only the legal form of its economic activities. It is also a special form historically conceived for productive activities, but not necessarily appropriate for the creative nature of contemporary enterprises. Second, it invites us to add a new dimension to the theories of the corporation, that of the purpose, the contribution to the world that the enterprise intends to achieve.

Clearly, the practical effects of this new form of governance remain to be evaluated. However, at this stage, the positive view of the enterprise that is embedded in this law invites researchers in business ethics to explore new legal and governance frameworks that are appropriate for contemporary enterprises.

In this way, the French proposal calls for important further research. It will, of course, be useful to follow the effects of this legal change at various levels: who is adopting société à mission status, what are their missions and how are they evaluated? Does the reform protect and secure CSR, and does it offer an effective framework for responsible innovation? More generally, the new law challenges our theories of the corporation and suggests that it is possible to conceive alternative forms of business law. Thus, it calls for further research to explore alternative legal frameworks for innovative and responsible enterprises in the twenty-first century.

\section{Compliance with Ethical Standards}

Conflict of interest The authors declare that they have no conflict of interest.

Informed Consent Informed consent was obtained from all individual participants included in the study. 
Open Access This article is licensed under a Creative Commons Attribution 4.0 International License, which permits use, sharing, adaptation, distribution and reproduction in any medium or format, as long as you give appropriate credit to the original author(s) and the source, provide a link to the Creative Commons licence, and indicate if changes were made. The images or other third party material in this article are included in the article's Creative Commons licence, unless indicated otherwise in a credit line to the material. If material is not included in the article's Creative Commons licence and your intended use is not permitted by statutory regulation or exceeds the permitted use, you will need to obtain permission directly from the copyright holder. To view a copy of this licence, visit http://creativecommons.org/licenses/by/4.0/.

\section{References}

Aguilera, R. V., Desender, K., Bednar, M. K., \& Lee, J. H. (2015). Connecting the dots: Bringing external corporate governance into the corporate governance puzzle. Academy of Management Annals, $9(1), 483-573$.

André, R. (2012). Assessing the accountability of the benefit corporation: Will this new gray sector organization enhance corporate social responsibility? Journal of Business Ethics, 110(1), $133-150$.

Auvray, T., Dallery, T., \& Rigot, S. (2016). L'entreprise liquidée. Michalon, Paris: La finance contre l'investissement.

Bainbridge, S. M. (1992). Interpreting nonshareholder constituency statutes. Pepperdine Law Review, 19, 991-1025.

Barthet, E. (2018). Le gouvernement lance le chantier du statut de l'entreprise. Le Monde. Paris. Retrieved from https://www.lemon de.fr/economie/article/2018/01/06/le-gouvernement-lance-lechantier-du-statut-de-1-entreprise_5238266_3234.html.

Bercy. (2017). PACTE: Restitution des travaux conduits par les parlementaires et les chefs d'entreprise. Retrieved from https ://www.entreprises.gouv.fr/files/files/directions_services/polit ique-et-enjeux/entrepreneuriat/dossier-presse-plan-dactioncroissance-et-transformation-des-entreprises-PACTE-dec 20 17.pdf

Berle, A., \& Means, G. (1932). The modern corporation and private property (Reed 1991). New Brunswick, NJ: Transaction Publishers.

Biondi, Y., Canziani, A., \& Kirat, T. (Eds.). (2007). The firm as an entity: Implications for economics, accounting, and the law. London: Routledge.

Bisconti, A. (2009). The double bottom line: Can constituency statutes protect socially responsible corporations stuck in Revlon land? Loyola of Los Angeles Law Review, 42, 765-806.

Blair, M. M., \& Stout, L. A. (1999). A team production theory of corporate law? Journal of Corporation Law, 24(4), 751-807.

Bratton, W. W. (1989). The new economic theory of the firm: Critical perspectives from history. Faculty Scholarship. University of Pennsylvania Law School, paper 333.

Chandler, A. D. (1977). The visible hand: The managerial revolution in American business. Cambridge, Mass: Belknap Press.

Chandler, A. D. (1990). Scale and scope: The dynamics of industrial capitalism. Cambridge: Harvard University Press.

Ciepley, D. (2018). Can corporations be held to the public interest, or even to the law? Journal of Business Ethics. https://doi. org/10.1007/s10551-018-3894-2.

Clark, W. H., \& Babson, E. K. (2012). How benefit corporations are redefining the purpose of business corporations. William Mitchell Law Review, 38(2), 817-851.

Clarke, T., O'Brien, J., \& O'Kelley, C. R. T. (Eds.). (2019). The Oxford handbook of the corporation. Oxford: Oxford University Press.
Club des Juristes. (2018). Le rôle sociétal de l'entreprise. Éléments de réflexion pour une réforme. Retrieved from https://www.leclu bdesjuristes.com/wp-content/uploads/2018/04/cdj_rapport_rolesocietal-entreprise_avril-2018.pdf

Deakin, S. (2009). Legal origin, juridical form and industrialization in historical perspective: The case of the employment contract and the joint-stock company. Socio-Economic Review, 7, 35-65.

Deakin, S. (2017). Tony Lawson's theory of the corporation: Towards a social ontology of law. Cambridge Journal of Economics, 41(5), 1505-1523. https://doi.org/10.1093/cje/bex044.

Deakin, S., Gindis, D., Hodgson, G. M., Huang, K., \& Pistor, K. (2017). Legal institutionalism: Capitalism and the constitutive role of law. Journal of Comparative Economics, 45(1), 188-200. https://doi.org/10.1016/j.jce.2016.04.005.

Deskins, B. M. R. (2012). Benefit corporation legislation, version 1.0: A breakthough in stakeholder rights? Lewis \& Clark Law Review, 15(4), 1047-1077.

Dine, J. (2000). The Governance of Corporate Groups. Cambridge: Cambridge University Press.

Djelic, M.-L. (2013). When limited liability was (still) an issue: Mobilization and politics of signification in 19th-century England. Organization Studies, 34(5-6), 595-621. https://doi. org/10.1177/0170840613479223.

Dodd, E. M. J. (1932). For whom are corporate managers trustees? Harvard Law Review, 45, 1145-1162.

Favereau, O. (2014). Entreprises: La grande déformation. Collège des Bernardins, Paris: Parole et Silence.

Favereau, O., \& Roger, B. (2015). Penser l'entreprise. Collège des Bernardins, Paris: Nouvel horizon du politique. Parole et Silence.

Filatotchev, I., \& Nakajima, C. (2014). Corporate governance, responsible managerial behavior, and corporate social responsibility: Organizational efficiency versus organizational legitimacy? Academy of Management Perspectives, 28(3), 289-306.

Grandori, A. (2010). Asset commitment, constitutional governance and the nature of the firm. Journal of Institutional Economics, $6(3), 351-375$.

Grandori, A. (2019). The firm in search of its nature. European Management Review, 16(1), 81-92. https://doi.org/10.1111/ emre.12178

Grinbaum, A., \& Groves, C. (2013). What is 'responsible' about responsible innovation? Understanding the ethical issues. In: R. Owen, J. Bessant, \& M. Heintz (eds.), Responsible innovation. London: Wiley.

Guinnane, T., Harris, R., Lamoreaux, N. R., \& Rosenthal, J.-L. (2007). Putting the corporation in its place. Enterprise \& Society, 8(3), 687-729.

Guinnane, T. W., Harris, R., \& Lamoreaux, N. R. (2017). Contractual freedom and corporate governance in Britain in the late nineteenth and early twentieth centuries. Business History Review, 91(2), 227-277.

Hansmann, H., \& Kraakman, R. (2000). Organizational law as asset partitioning. European Economic Review, 44(4-6), 807-817.

Hemphill, T. A., \& Cullari, F. (2014). The benefit corporation: Corporate governance and the for-profit social entrepreneur. Business \& Society Review, 119(4), 519-536. https://doi.org/10.1111/ basr.12044.

Hiller, J. S. (2013). The benefit corporation and corporate social responsibility. Journal of Business Ethics, 118(2), 287-301. https ://doi.org/10.1007/s10551-012-1580-3.

Ireland, P. (2010). Limited liability, shareholder rights and the problem of corporate irresponsibility. Cambridge Journal of Economics, 34(5), 837-856. https://doi.org/10.1093/cje/ben040.

Jensen, M. C., \& Meckling, W. H. (1976). Theory of the firm: Managerial behavior, agency coss and ownerships structure. Journal of Financial Economics, 3(4), 305-360. https://doi.org/10.2139/ ssrn.94043. 
Kaufman, A., \& Englander, E. (2005). A team production model of corporate governance. Academy of Management Executive, 19(3), $9-24$.

Keay, A. (2007). Tackling the issue of the corporate objective: An analysis of the United Kingdom's 'enlightened shareholder value approach'. Sydney Law Review, 29, 577-612.

Lan, L. L., \& Heracleous, L. (2010). Rethinking agency theory: The view from law. Academy of Management Review, 35(2), 294-314.

Lazonick, W. (2014). Profits without prosperity. Harvard Business Review, 92(9), 46-55.

Lefebvre-Teillard, A. (1985). La Société anonyme au 19ème. Paris: Presses Universitaires de France.

Levillain, K. (2017). Les entreprises à mission. Vuibert, Paris: Un modèle de gouvernance pour l'innovation dans l'intérêt commun.

Mac Cormac, S. H., \& Haney, H. (2012). New corporate forms: One viable solution to advancing environmental sustainability. Journal of Applied Corporate Finance, 24(12), 1-8.

Margolis, J. D., \& Walsh, J. P. (2003). Misery loves companies: Rethinking social initiatives by business. Administrative Science Quarterly, 48(2), 268-305.

Mayer, C. (2013). Firm commitment: Why the corporation is failing us and how to restore trust in it?. Oxford: Oxford University Press.

McMullen, J. S., \& Warnick, B. J. (2016). Should we require every new venture to be a hybrid organization? Journal of Management Studies, 53(4), 630-662. https://doi.org/10.1111/joms.12150.

Metcalf, L., \& Benn, S. (2012). The corporation is ailing social technology: Creating a 'fit for purpose' design for sustainability. Journal of Business Ethics, 111(2), 195-210. https://doi.org/10.1007/ s10551-012-1201-1.

Michelle, C. (2017). Benefit corporations in the United States and community interest companies in the United Kingdom: Does social enterprise actually work? Northwestern Journal of International Law \& Business, 37(1), 149-172.

Millon, D. (1990). Theories of the corporation. Duke Law Journal, 2, 201.

Millon, D. (2007). Piercing the corporate veil, financial responsibility, and the limits of limited liability. Emory Law Journal, 56(5), $1308-1382$.

Mulgan, T. (2018). Corporate agency and possible futures. Journal of Business Ethics. https://doi.org/10.1007/s10551-018-3887-1.

O'Kelley, C. R. T. (2019). From Berle to the present: The shifting primacies of corporation theory. In T. Clarke, J. O'Brien, \& C. R. T. O'Kelley (Eds.), The Oxford handbook of the corporation (pp. 119-138). Oxford: Oxford University Press.

Orts, E. W. (1992). Beyond shareholders: Interpreting corporate constituency statutes. George Washington Law Review, 14(1), $14-135$.

Perrow, C. (2002). Organizing America. Wealth, power and the origins of corporate capitalism. Princeton: Princeton University Press.

Rajan, R. G., \& Zingales, L. (2000). The governance of the new entreprise. In: X. Vives (Ed.), Corporate governance. Theoretical and empirical perspectives. Cambridge: Cambridge University Press.

Rawhouser, H., Cummings, M., \& Crane, A. (2015). Benefit corporation legislation and the emergence of a social hybrid category. California Management Review, 57(3), 13-35. https://doi. org/10.1525/cmr.2015.57.3.13.

Robé, J.-P. (1999). L'Entreprise et le Droit. Paris: PUF.

Robé, J.-P. (2011). The legal structure of the firm. Accounting, Economics, and Law, 1(1), 1-86.

Roger, B. (Ed.). (2012). L'entreprise, formes de la propriété et responsabilités sociales. Paris: Parole et Silence.
Roy, W. G. (2019). Socializing capital: The rise of the industrial corporation. In T. Clarke, J. O’Brien, \& C. R. T. O'Kelley (Eds.), The Oxford handbook of the corporation (pp. 93-117). Oxford: Oxford University Press.

Sandberg, J. (2011). Socially responsible investment and fiduciary duty: Putting the freshfields report into perspective. Journal of Business Ethics, 101(1), 143-162. https://doi.org/10.1007/s1055 1-010-0714-8.

Scherer, A. G., Baumann-Pauly, D., \& Schneider, A. (2013). Democratizing corporate governance: Compensating for the democratic deficit of corporate political activity and corporate citizenship. Business \& Society, 52(3), 473-514. https://doi. org/10.1177/0007650312446931.

Scherer, A. G., \& Palazzo, G. (2007). Toward a political conception of corporate responsibility: Business and society seen from a Habermasian perspective. Academy of Management Review, 32(4), 1096-1120.

Scherer, A. G., \& Voegtlin, C. (2017). Corporate governance for responsible innovation: Approaches to corporate governance and their implications for sustainable development. Academy of Management Perspectives. https://doi.org/10.5465/amp.2017.0175.

Segrestin, B., \& Hatchuel, A. (2011). Beyond agency theory, a postcrisis view of corporate law. British Journal of Management, 22(3), 484-499.

Segrestin, B., \& Hatchuel, A. (2012). Refonder l'entreprise (La République des Idées). Paris: Le Seuil.

Segrestin, B., Levillain, K., Vernac, S., \& Hatchuel, A. (Eds.). (2015). La Société à Objet Social Etendu: Un nouveau statut pour l'entreprise (Economie Gestion). Paris: Presses des Mines.

Segrestin, B., \& Vernac, S. (2018). Gouvernement, participation et mission de l'entreprise. Paris: Herman.

Smith, N. C., \& Rönnegard, D. (2016). Shareholder primacy, corporate social responsibility, and the role of business schools. Journal of Business Ethics, 134(3), 463-478. https://doi.org/10.1007/s1055 1-014-2427-x.

Starbuck, W. H. (2014). Why corporate governance deserves serious and creative thought. Academy of Management Perspectives, 28(1), 15-21. https://doi.org/10.5465/amp.2013.0109.

Stout, L. (2019). Corporations as sempiternal legal persons. In T. Clarke, J. O'Brien, \& C. R. T. O'Kelley (Eds.), The Oxford handbook of the corporation (pp. 220-235). Oxford: Oxford University Press.

Teubner, G. (1988). Enterprise corporatism: New industrial policy and the 'essence' of the legal person. The American Journal of Comparative Law, 36(1), 130-155. https://doi.org/10.2307/840187.

Vernac, S. (2015). Pour une réhabilitation de l'objet social. In B. Segrestin, K. Levillain, S. Vernac, \& A. Hatchuel (Eds.), La Société à Objet Social Etendu. Unnouveau statut pour l'entreprise (pp. 61-74). Paris: Presses des Mines.

Veldman, J. (2018). The separate legal entity and the architecture of the modern corporation. In N. Boeger \& C. Villiers (Eds.), Shaping the corporate landscape: Towards corporate reform and enterprise diversity (pp. 61-75). Bloomsbury: Hart Publishing.

Yosifon, D. G. (2014). The law of corporate purpose. Berkeley Business Law Journal, 10, 181-230.

Yosifon, D. G. (2017). Opting out of shareholder primacy: Is the public benefit corporation trivial? Delaware Journal of Corporate Law, 41(2), 461-508.

Publisher's Note Springer Nature remains neutral with regard to jurisdictional claims in published maps and institutional affiliations. 